\title{
In vitro Characterization and Evaluation of Commercialized Paracetamol Products in Jordan
}

\author{
Ola A. Tarawneh ${ }^{1 *}$, Atif M Madi ${ }^{2}$, Rania Hamed ${ }^{1}$, Rania Qirem ${ }^{1}$, Walid Qerem ${ }^{1}$, Ala Alhusban ${ }^{1}$, Suhair \\ Sunoqrot ${ }^{1}$, Nouf Mahmoud ${ }^{1}$, Samah Ata ${ }^{1}$, and lyad Alsheikh ${ }^{1}$ \\ ${ }^{1}$ Al-Zaytoonah University of Jordan, Faculty of Pharmacy, Amman, Jordan \\ ${ }^{2}$ Trinity College Dublin, School of Pharmacy and Pharmaceutical Sciences, Dublin, Ireland
}

e-mail: ola.tarawneh@zuj.edu.jo

\section{ABSTRACT}

Paracetamol (acetaminophen) is one of the most commonly used antipyretic and analgesic drugs worldwide. It is the drug of choice for patients with bronchial asthma, hemophilia, salicylate hypersensitivity, peptic ulcer, and pregnant or breastfeeding women who cannot be treated with nonsteroidal anti-inflammatory drugs. It is marketed and manufactured by many pharmaceutical companies, which necessitates the requirement of quality control investigation. A post-market evaluation was conducted on five commercial paracetamol products ( $500 \mathrm{mg}$ ) available in Jordan, which involved quality control testing in terms of dissolution, disintegration, weight variation, and glass transition temperature (Tg) determination using dynamic mechanical thermal analysis (DMTA). Dissolution and disintegration of the five products were compared under two different conditions, compendial United States Pharmacopeial Convention (USP) and non-compendial. Compendial experiments were conducted under $\mathrm{pH}$ 5.8, and non-compendial testing was carried out under $\mathrm{pH}$ 1.2. Results revealed variations in the dissolution patterns at the different $\mathrm{pH}$ conditions for the same formulation. Generally, faster dissolution was observed when testing the dissolution in compendial USP conditions; $\mathrm{pH} 5.8$ compared to $\mathrm{pH}$ 1.2. Disintegration was also affected by $\mathrm{pH}$ in the tested formulations. Tg detected via DMTA of the tested formulation was ranged from $18.82 \pm 0.77^{\circ} \mathrm{C}$ to $23.13 \pm 2.46{ }^{\circ} \mathrm{C}$. No correlation was found between $\mathrm{Tg}$ variation and drug dissolution. In general, all products met the compendial requirements despite their differences in the early stages of dissolution profiles. Our work highlights the importance of post-market quality control testing of generic equivalents of immediate release dosage forms, which is essential for improving upon existing formulations. It also introduces DMTA as an informative tool for detecting thermal transitions of active pharmaceutical ingredients (APIs) in solid oral dosage forms.

KEYWORDS: Paracetamol, dissolution, dynamic mechanical thermal analysis, compendial USP, immediate release

\section{INTRODUCTION}

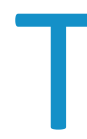

he current research-based pharmaceutical industry has demonstrated a decline return on investment from research and development over the last few years (1). As a result, it may be deemed appropriate to invest in the current commercial products. Post-market assessment includes all activities conducted, such as the quality, therapeutic effectiveness and safety, to obtain more data after the product has been released to the market (2). One of the imperative indicators of product quality is in vitro testing of dissolution rate. Dissolution cannot be ruled out from the assessment of newly developed formulations in addition to commercially available products to ensure product efficiency. Although no clear data correlate dissolution to absorption and bioavailability (1), many authors claim that the rate of drug release impacts bioavailability and could enhance the pharmacological response in a short period of time (3).

Quality control testing is a set of routine analytical experiments that are conducted in order to maintain batch to batch variation and eventually protect the end user $(3,4)$. In vitro dissolution testing is an imperious indicator of official product monographs (5). This test is designed mainly for quality control purposes and it remains unclear whether in vivo outcomes could be anticipated through it (5). In order to approach the in vivo outcomes, Markopoulos et al. explained the selection of the appropriate level of simulation of the in vivo media

*Corresponding author 
and conditions for performance assessment of orally administered drug products in vitro (6). The authors classified the dissolution media into four levels, from level 0 (physiologically irrelevant, but with variations in $\mathrm{pH}$ ), to level III (the most complex containing many components such as proteins and enzymes). Regardless of the complexity of the dissolution media in those levels, $\mathrm{pH}$ is a key element in assessing dissolution (6). Dressman et al revealed that the change in $\mathrm{pH}$ could dramatically affect the solubility of drugs, which, in turn, can affect the oral bioavailability (7).

Paracetamol (acetaminophen) is a widely available, overthe-counter drug. It is dispensed worldwide under many brand names, dosage forms, and strengths. Paracetamol is a weak acid with a pKa of 9.5. Paracetamol solubility is estimated to be $23.7 \mathrm{mg} / \mathrm{mL}$ at $37{ }^{\circ} \mathrm{C}$. In its highest available strength, i.e., $500 \mathrm{mg}$, the dose to solubility ratio is $21 \mathrm{~mL}$. This value is less than $250 \mathrm{~mL}$, the minimum for an active pharmaceutical ingredient (API) to be highly soluble, as defined by the Biopharmaceutics Classification System (BCS) guidance (8). The BCS classifies APIs according to their solubility and permeability. BSC is considered a waiver tool for predicating bioequivalence studies $(8,9)$.

The compendial requirements for paracetamol dissolution according to the USP state that it is conducted in $900 \mathrm{~mL}$ of phosphate buffer (pH 5.8), using USP type II (paddle) apparatus at $50 \mathrm{rpm}$, with ultraviolet (UV) measurement at $243 \mathrm{~nm}$. At least $80 \%$ of the labeled drug amount must be dissolved in the first $30 \mathrm{~min}(10)$. Although dynamic mechanical thermal analysis (DMTA) is not an official requirement in quality control testing, it could be a valuable tool in relation to drug release and mechanical properties $(11,12)$. DMTA involves the application of an external force while measuring the resulting deformation of the solid material. It is perhaps the most easily accessible, rapid, and nondestructive way of quantifying the rheological and mechanical properties of materials. Therefore, the application of DMTA for the characterization of drug delivery systems has gained greater attention (13). Thus, this is the first reported DMTA measurement of commercially available paracetamol products in Jordan utilized to detect glass transition temperature $(\mathrm{Tg})$.

The main purpose of this study was to compare the results of dissolution, disintegration, weight variation, assay, and Tg with post-marketing quality control tests of five commercial paracetamol products in Jordan. This study also investigated the variation between dissolution and disintegration profiles at different $\mathrm{pH}$ values referring to compendial ( $\mathrm{pH}$ 5.8) and non-compendial $(\mathrm{pH}$ 1.2) conditions.

\section{METHODS AND MATERIALS}

Five commercially available paracetamol (acetaminophen) products (500 $\mathrm{mg}$ ) were tested. The products were encrypted as product 1 tablet (Julphar Gulf Pharmaceutical Industries, UAE), product 2 round tablet (The Arab Pharmaceutical Manufacturing Co. Ltd., Jordan), product 3 caplet (GlaxoSmithKline, UK), product 4 (GlaxoSmithKline, UK), and product 5 round tablet (Jordan Sweden (JOSWE) Medical and Sterilization Company, Jordan). Potassium dihydrogen phosphate, sodium hydroxide, and hydrochloric acid were obtained from Sigma-Aldrich (St Louis, MO, USA). All materials were of analytical grade or higher and were used as received without further purification.

\section{Sample Collection}

The label claim for all five products was $500 \mathrm{mg}$ of paracetamol per tablet. The labeled shelf life of all the products was 3 years from the date of manufacturing, and samples were taken for the evaluation 2 years prior to the labeled expiry date.

\section{Weight Variation}

Twenty tablets of each product were weighed individually, and the mean weight of each product and the percentage deviation from the mean value were calculated.

\section{Assay}

Paracetamol tablets $(n=20)$ were weighed individually and ground. Powdered paracetamol (mass equivalent to $0.15 \mathrm{~g}$ of each product) was dissolved in $50 \mathrm{~mL}$ of 0.1 $\mathrm{M} \mathrm{NaOH}$ and transferred to a $250-\mathrm{mL}$ volumetric flask. The volume was then completed to $250 \mathrm{~mL}$ with distilled water. The flask was then shaken vigorously for $15 \mathrm{~min}$ and the solution was filtered. Then, $10 \mathrm{~mL}$ of filtrate was diluted to $100 \mathrm{~mL}$ by distilled water. After that, $10 \mathrm{~mL}$ of the resulting solution was transferred into a flask where $10 \mathrm{~mL}$ of $0.1 \mathrm{M} \mathrm{NaOH}$ was added. The resultant mixture was then diluted to $50 \mathrm{~mL}$ with distilled water and mixed thoroughly by shaking. The absorbance of the resulting solution was measured at $243 \mathrm{~nm}$ using a UV-1800 spectrophotometer (Shimadzu, Japan) (10).

\section{Disintegration Test}

The disintegration time of the tablets was determined in two different media, phosphate buffer pH 5.8 and hydrochloric acid $(\mathrm{HCl}) \mathrm{pH} 1.2$, in a QC-21 Disintegration Tester (Teledyne Hanson Research, USA). Tablets were 
placed on the wire mesh just above the surface of the media in the tube. The tubes were placed in $800 \mathrm{~mL}$ of media at $37 \pm 0.5{ }^{\circ} \mathrm{C}$. The time taken for each tablet to disintegrate and all the granules to go through the wire mesh was recorded. Results were expressed as an average of six determinations (14).

\section{Dissolution Test}

Commercially available paracetamol (500-mg), immediate-release dosage forms of each product $(n=6$ for each) were immersed in $900 \mathrm{~mL}$ of pre-warmed media at $37^{\circ} \mathrm{C}(\mathrm{HCl} \mathrm{pH} 1.2$ and phosphate buffer $\mathrm{pH}$ 5.8) in USP type II paddle apparatus (Dissolution Tester SR6, Teledyne Hanson Research, USA) at $50 \mathrm{rpm}$. At predetermined time intervals $(15,30,45$, and $60 \mathrm{~min})$, aliquots were withdrawn and replaced with fresh pre-warmed media to maintain a constant volume throughout the experiment. The mass of paracetamol released was analyzed using UV spectroscopy at $243 \mathrm{~nm}$ and was calculated with reference to a previously constructed calibration curve in each release medium $\left(R^{2}>0.99\right)$. The percentage of released drug was then plotted against time (10).

\section{Dynamic Mechanical Thermal Analysis}

For a material, the storage modulus $\left(E^{\prime}\right)$ is the elastic modulus and the loss modulus ( $\left.E^{\prime \prime}\right)$ is the viscous modulus. The tangent of the loss angle, $\tan \delta$, is the ratio of the viscous modulus to the elastic modulus: $\operatorname{Tan} \delta=$ loss modulus ( $\left.E^{\prime \prime}\right) /$ storage modulus ( $\left.E^{\prime}\right)$.

The $\mathrm{Tg}$ value of the powdered tablets was determined using a Dynamic Mechanical Analyzer (Q800 DMA, Instruments, Inc., USA). Tablets $(n=3)$ were ground, and the powder was transferred to a rectangular tray. The temperature scan was performed at a heating rate of $3^{\circ} \mathrm{C} / \mathrm{min}$ in the range of $0-180^{\circ} \mathrm{C}$. Measurement of $E^{\prime}$ and $E^{\prime \prime}$ for calculation of $\tan \delta$ was carried out at $1 \mathrm{~Hz}$. The $\mathrm{Tg}$ value was detected from the peak maximum of $\tan \delta(12)$.

\section{Statistical Analysis}

The independent sample t-test was employed to compare the dissolution rates for each product in $\mathrm{HCl}(\mathrm{pH}=1.2)$ against phosphate buffer $(\mathrm{pH}=5.8)$ at each time point. A factorial analysis of variance (ANOVA), which included drug and $\mathrm{pH}$ as independent variables and dissolution rate at each time point as the dependent variable, was used to compare the dissolution rates between the different products at different $\mathrm{pH}$ values, followed by post hoc analysis. Differences in dissolution rates between different time points were calculated for each test and repeated measures of ANOVA was conducted, which included drug and $\mathrm{pH}$ as independent variables; post hoc analysis was also conducted. A $p$ value less than 0.05 was considered significant. SPSS 23 (IBM, USA) was used to conduct the statistical analysis. Pearson's correlation ( $r$ ) was used to measure the correlation between $\mathrm{Tg}$ and dissolution rate at each time point.

\section{RESULTS}

\section{Assay, Disintegration, and Glass Transition}

Table 1 demonstrates the assay of the tested formulations. The USP states that acetaminophen (paracetamol) tablets should contain not less than $90.0 \%$ and not more than $110.0 \%$ of the labeled amount. All tablets had an assay that was compliant with the requirements except for product 1 , which showed an assay of $87.85 \%$. Considering the disintegration results of the tested formulations; one-way ANOVA showed significant difference in the disintegration profile and was $\mathrm{pH}$ dependent. As shown in Table 1, product 1 demonstrated the longest time of disintegration, which took $30.85 \pm$ 0.17 min for disintegration at $\mathrm{pH} 1.2$ followed by product 2 which took $2.94 \pm 0.07$ min. Products 4 and 5 showed similar disintegration $(p=0.782)$, followed by product 3 , which demonstrated the shortest disintegration time at $1.51 \pm 0.05 \mathrm{~min}$. On the other hand, at $\mathrm{pH} 5.8$, products 3,4 , and 5 demonstrated similar disintegration times, ( $p$ $>0.05$ ), which were less than $2.17 \mathrm{~min}$. Product 2 had a disintegration time of $5.92 \pm 0.11 \mathrm{~min}$, and product 1 had the longest time for disintegration (19.96 $\pm 0.07 \mathrm{~min})$.

Table 1. Disintegration Time for Selected Paracetamol (Acetaminophen) Products $(500 \mathrm{mg}$ )

\begin{tabular}{|c|c|c|c|c|}
\hline Formulation & Assay (\%) & $\begin{array}{c}\text { Time to } \\
\text { disintegrate } \\
\text { at } \mathrm{pH} \mathrm{1.2} \\
(\mathrm{min})\end{array}$ & $\begin{array}{c}\text { Time to } \\
\text { disintegrate } \\
\text { at } \mathrm{pH} \mathrm{5.8} \\
(\mathrm{min})\end{array}$ & $\begin{array}{c}\text { Weight } \\
\text { variation }(\mathrm{g})\end{array}$ \\
\hline Product 1 & 87.85 & $30.85 \pm 0.17$ & $19.96 \pm 0.07$ & $0.676 \pm 0.002$ \\
\hline Product 2 & 97.28 & $2.94 \pm 0.07$ & $5.92 \pm 0.11$ & $0.599 \pm 0.003$ \\
\hline Product 3 & 101.45 & $1.51 \pm 0.05$ & $2.17 \pm 0.03$ & $0.551 \pm 0.002$ \\
\hline Product 4 & 103.03 & $2.42 \pm 0.03$ & $1.98 \pm 0.02$ & $0.556 \pm 0.002$ \\
\hline Product 5 & 98.07 & $2.36 \pm 0.03$ & $2.02 \pm 0.02$ & $0.579 \pm 0.001$ \\
\hline
\end{tabular}

The Tg values ( $n=3$ at least) are presented in Table 2 . The DMTA studies showed that product 4 exhibited a $\mathrm{Tg}$ of $23.13 \pm 2.46^{\circ} \mathrm{C}$, which was statistically significantly higher than product 1 and 2 ( $p=0.016$ and 0.01 , respectively) and was similar to products 3 and $5(p>0.101$ and 0.230 , respectively). Tg of product 3 was similar to all formulations ( $p>0.05$ in all cases). 
Table 2. Glass Transition Temperature (Tg) for Selected Paracetamol (Acetaminophen) Products $(500 \mathrm{mg}$ )

\begin{tabular}{|c|c|}
\hline Formulation & $\mathrm{Tg}\left({ }^{\circ} \mathrm{C}\right)$ \\
\hline Product 1 & $19.13 \pm 0.47$ \\
\hline Product 2 & $18.82 \pm 0.77$ \\
\hline Product 3 & $20.32 \pm 0.35$ \\
\hline Product 4 & $23.13 \pm 2.46$ \\
\hline Product 5 & $20.59 \pm 2.12$ \\
\hline
\end{tabular}

\section{Dissolution Studies}

The dissolution profiles of paracetamol are shown in Figures 1 (pH 1.2) and 2 (pH 5.8). At pH 1.2, slower drug release at the early stages (15 $\mathrm{min}$ ) of the experiment was observed for product 2 . Product 1 showed slower release than product 3 and 5 at the same time point. At 30 min, all formulations exhibited release patterns that exceeded $80 \%$ and were statistically similar. The drug release profile at $\mathrm{pH} 1.2$ for the tested products revealed significantly lower values when compared to their corresponding time points at $\mathrm{pH} 5.8$ ( $p<0.05$ in all cases). For example, product 2 at $\mathrm{pH} 1.2$ released $57.9 \% \pm 4.1 \%$ after $15 \mathrm{~min}$ (Fig. 1), which was statistically significantly lower than $\mathrm{pH}$ $5.8(77.76 \% \pm 6.43 \% ; p=0.000)$ at the same time point (Fig. 2).

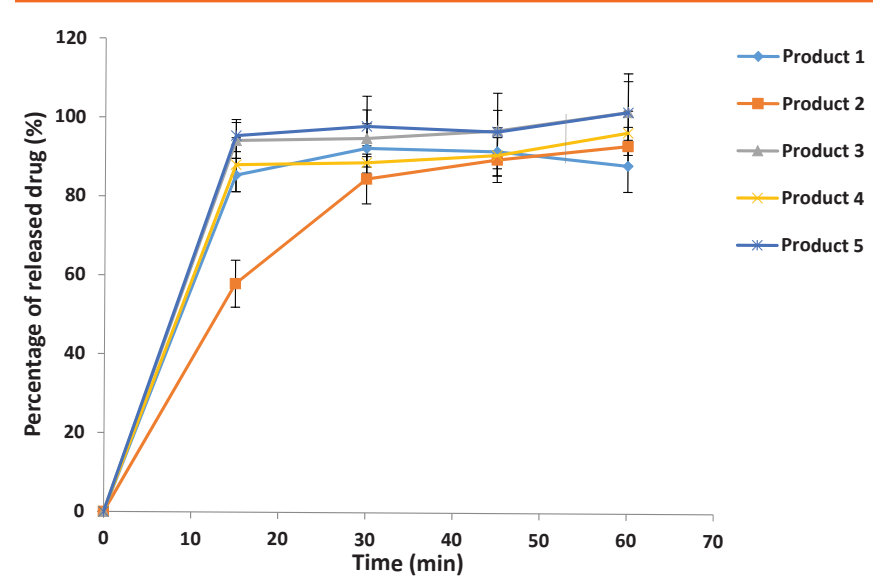

Figure 1. Drug release profiles of selected paracetamol (acetaminophen) products $(500 \mathrm{mg}$ ) in $900 \mathrm{~mL}$ of hydrochloric acid at pH 1.2 with USP apparatus II at $50 \mathrm{rpm}, 37^{\circ} \mathrm{C}$.

At $\mathrm{pH} 5.8$, the release of product 2 was statistically significantly lower compared to all other tested products at the 15 -min time point $(p<0.05)$. Likewise, at the 15 -min time point, product 1 showed significantly lower release than products 3,4 , and $5(p<0.05)$, with a value of $91.0 \% \pm$ $2.0 \%$. At $30 \mathrm{~min}$, the percentage of drug released reached $80 \%$ or more in all formulations, which is consistent with the compendial requirements.

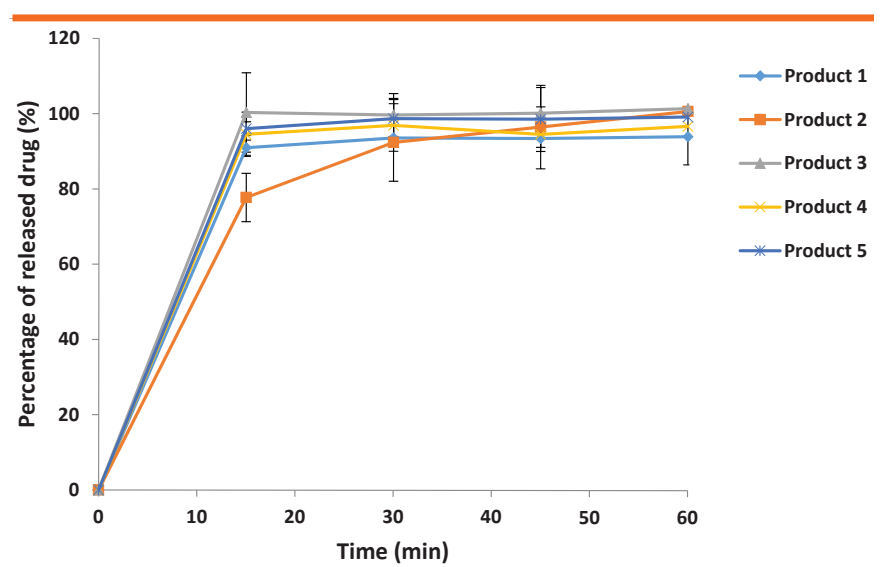

Figure 2. Drug release profile of selected paracetamol (acetaminophen) products $(500 \mathrm{mg})$ in $900 \mathrm{~mL}$ of phosphate buffer at pH 5.8 with USP apparatus II at $50 \mathrm{rpm}, 37^{\circ} \mathrm{C}$.

\section{DISCUSSION}

Paracetamol (BCS Class III, high solubility, low permeability) is an over-the-counter antipyretic and analgesic therapeutic agent, it is a white crystalline powder that is sparingly soluble in water. Paracetamol has a melting range from $169-172{ }^{\circ} \mathrm{C}$ (15). Its peak plasma concentration is achieved within 0.17-1.2 $\mathrm{h}$ (16). This study focuses on the variation between different paracetamol $(500 \mathrm{mg}$ ) immediate-release dosage forms regarding assay, disintegration, and dissolution. Also, it introduces the measurement of Tg through using DMTA, which is one of the most sensitive tools for detecting $\mathrm{Tg}$ $(17,18)$.

\section{Disintegration and Dissolution}

Disintegration is the break down process of tablets into smaller particles and is the first step towards dissolution. Dissolution is a crucial quality control parameter that is necessary to limit batch to batch variation and ensure reproducible bioavailability $(3,19)$. Subsequently, rapid dissolution will likely suggest a faster absorption and bioavailability (3). The compendial requirements for immediate-release paracetamol tablets state that release is tolerated if not less than $80 \%$ of the labeled amount is dissolved within $30 \mathrm{~min}$ (10). The release profile of five commercially available products employed in this study show that this requirement was met and that all formulations demonstrated similar release patterns. Yet, earlier time points are significantly different between the first determined time points (15 $\mathrm{min}$ ) when compared to the late stages ( 45 and $60 \mathrm{~min}$ ). This could be due to the effect of excipients like superdisintegrants and disintegrants. Superdisintegrants are crosslinked polymers that swell when being in contact with water (20). 
The type of media is known to have an effect on drug release and dissolution (21). The determination of an in vitro dissolution test that accurately predicts in vivo behaviour dissolution is therefore essential. The compendial USP testing of paracetamol dissolution states that the release is tested at $\mathrm{pH}$ 5.8. Paracetamol is a weak acid; accordingly, it would be expected to have a faster release at pH 5.8 than at pH 1.2. Nevertheless, the stomach has an acidic $\mathrm{pH}$ and drug release is reported to be tested at $\mathrm{pH} 1.2$ in published literature to mimic the in vivo conditions (22). The results showed a slower dissolution rate at $\mathrm{pH} 1.2$ for all products, which suggests that manufacturers may run parallel dissolution testing; one at the compendial stated $\mathrm{pH}$ in the USP and another $\mathrm{pH}$ that could be related to the in vivo conditions.

The standard disintegration time for USP uncoated tablet must be as low as $5 \mathrm{~min}$, and the majority of the tablets have a maximum disintegration time of $30 \mathrm{~min}$ (23). The disintegration time could be reflected on the release results, especially in the early stages. For example, disintegration time was longer in the case of products 1 and 2 compared to the other formulations. And, Product 2 showed significantly lower release at $15 \mathrm{~min}$ compared to all other formulations (Figs. 1 and 2). Though, in a study conducted by Afifi and colleagues, the disintegration of product 5 was found to be $18 \mathrm{~min}$, which is almost nine times higher than the disintegration time in our study $(2.02 \pm 0.02 \mathrm{~min}$ at $\mathrm{pH} 5.8$ and $2.36 \pm 0.03 \mathrm{~min}$ at $\mathrm{pH} 1.2)$ (24). This finding creates a huge gap that needs to be addressed; many reasons may lead to this difference, such as the time at which drugs were collected from the market or the storage conditions and humidity. In the same study conducted on product 2, disintegration was found to be $3.4 \mathrm{~min}$, which is similar to our findings ( 2.94 $\pm 0.07 \mathrm{~min}$ at $\mathrm{pH} 1.2$ and $5.92 \pm 0.11 \mathrm{~min}$ at $\mathrm{pH} 5.8$ ) (24).

The difference in paracetamol release profiles of the different products could be attributed to their composition and the method of manufacture (25-27). Immediate-release formulations usually contain variable excipients, such as diluent, glidant, antiadherent, disintegrant, superdisintegrants, and inorganic materials such as sodium bicarbonate. Table 3 lists the main ingredients of commercially available products, and Table 4 lists the main ingredients in the coating layer of products 3 and 4 . Notably, as Table 4 signifies, the coating layer did not affect the release pattern, as it is only employed to mask the taste.

The variation of the components of each product could explain the differences in paracetamol release profiles.
The method of manufacture may also influence the in vitro dissolution patterns. In addition, differences in composition can sometimes affect the extent of absorption, which has been previously reported (4). For example, product 4 contains sodium bicarbonate, which may initiate an acid-base reaction in the acidic stomach and release carbon dioxide, thus mimicking effervescent tablets, which could be related to the observed fast drug release from the dosage form (28). Product 4 attributes its fast effect to increased gastric emptying, initiated by the presence of sodium bicarbonate (29). A clinical investigation was conducted by Grattan et al on paracetamol commercial tablets in a five-way crossover study (28). The authors concluded that sodium bicarbonate increased the rate of absorption compared to other formulations and that the higher ratio led to a further increase in absorption rate (28).

Product 3 contains crospovidone, a superdisintegrant that is hygroscopic in nature $(30,31)$. In addition, product 3 contains alginic acid, a common disintegrant (32). Superdisintegrants exert their action by swelling, and the subsequent outward or radial, pressure generated leads to bursting or accelerated water absorption, ultimately promoting disintegration. Clearly, the effect of superdisintegrants was dominant in the early drug release seen in this study (31). Furthermore, the type of excipients appears to play an important parameter in the release. For example, the presence of the superdisintegrants in products 3 and 4 may have surpassed the influence of $\mathrm{Tg}$, where a high $\mathrm{Tg}$ was not relevant to the rate of dissolution. Considering that product 2 had similar Tg to product 1 , 3 , and 5, it did not exhibit a similar release profile. This could be attributed to the lack of superdisintegrants and sodium bicarbonate.

Product 2 did not include any superdisintegrants, which may explain why it showed lower release at both $\mathrm{pH}$ levels at the early stage compared to the tested formulations. Pregelatinized starch is present in different products, such as products 2,3 , and 4 . It is a modified starch prepared from potato starch and is used as disintegrant in dispersible tablets due to its superior swelling capacity (33). Product 2 also contains stearic acid, a lipid that could be responsible for the delay in the release. A similar observation was reported by Afifi and colleagues, where the authors described the variation of in vitro dissolution of each tablet to be within the prescribed limit, but product 2 showed slower dissolution rate at the early stages of the experiment compared to the other formulations (24). 
Table 3. Composition and Function of Selected Paracetamol (Acetaminophen) Products (500 mg)

\begin{tabular}{|c|c|c|c|c|}
\hline Function & Product 1 & Product 2 & Product 3 & Product 4 \\
\hline Fillers & $\begin{array}{l}\text { Maize starch (37) } \\
\text { Magnesium stearate }(38-40)\end{array}$ & Maize starch (37) & Magnesium stearate (38) & $\begin{array}{l}\text { Maize starch (37) } \\
\text { Magnesium stearate fillers (38) } \\
\text { Microcrystaline cellulose (41) }\end{array}$ \\
\hline Diluents & Maize starch (37) & Maize starch (37) & Calcium carbonate tablet (25) & $\begin{array}{l}\text { Maize starch (37) } \\
\text { Microcrystaline cellulose (41) }\end{array}$ \\
\hline Disintegrants & Maize starch $(38-40)$ & - & Colloidal anhydrous silica (25) & - \\
\hline Binder & $\begin{array}{l}\text { Povidone (42) } \\
\text { Gelatin powder (25) }\end{array}$ & $\begin{array}{l}\text { Polyvidone } \\
\text { (enhances dissolution of } \\
\text { poorly soluble drugs (25)) } \\
\text { Hypromellose (43) }\end{array}$ & $\begin{array}{l}\text { Calcium carbonate tablet (25) } \\
\text { Crospovidone (42) } \\
\text { Povidone (K-25) (42) }\end{array}$ & Povidone (42) \\
\hline Preservatives & Methyl and propyl paraben (5) & Potassium sorbate (25) & $\begin{array}{l}\text { Sodium propyl } \\
\text { parahydroxybenzoate (44) }\end{array}$ & Potassium sorbate (25) \\
\hline Solubilizing Agent & Glycerol (25) & - & - & - \\
\hline $\begin{array}{l}\text { Lubricant and/or } \\
\text { Antiadherent }\end{array}$ & $\begin{array}{l}\text { Magnesium stearate (25) } \\
\text { Talc (purified) (25) }\end{array}$ & $\begin{array}{l}\text { Purified talc (25) } \\
\text { Stearic acid (25) }\end{array}$ & $\begin{array}{l}\text { Magnesium stearate (25) } \\
\text { Colloidal anhydrous silica } \\
\text { glidant (25) }\end{array}$ & - \\
\hline $\begin{array}{l}\text { Compression } \\
\text { Enhancement }\end{array}$ & - & Starch pregelatinised (41) & Pregelatinised starch (41) & Starch pregelatinised (41) \\
\hline Humectant & - & Triacetin (25) & - & - \\
\hline Plasticizer & - & Triacetin (43) & - & - \\
\hline Stabilizing Agent & - & - & Alginic acid (25) & Microcrystaline cellulose (45) \\
\hline Anticaking Agent & - & - & Colloidal anhydrous silica (25) & - \\
\hline $\begin{array}{l}\text { Enhances Absorption, } \\
\text { Gastric Emptying }\end{array}$ & - & - & - & Sodium bicarbonate (16) \\
\hline Polishing Agent & - & - & - & Carnauba wax (25) \\
\hline
\end{tabular}

Table 4. Ingredients of Coated Layer in Paracetamol (Acetaminophen) Products 3 and $4(500 \mathrm{mg})$

\begin{tabular}{|l|l|l|}
\hline Function & Product 3 & Product 4 \\
\hline Film Forming Agent & Opadry white (43) & Opadry II Y-22-7719 white: titanium dioxide (46) \\
\hline Tablet smoothing & Opadry white (36) & Opadry II Y-22-7719 white: titanium dioxide (46) \\
\hline Tablet Polish & Carnauba wax (39, 40) & \\
\hline Preservatives & $\begin{array}{l}\text { Parahydroxybenzoates (sodium methyl) (47) } \\
\text { Sodium ethyl parahydroxybenzoate (43) } \\
\text { Parahydroxybenzoate (47) }\end{array}$ & \\
\hline Taste Masking & Carnauba wax (39, 40) & - \\
\hline Film Coating & $\begin{array}{l}\text { HPMC 2910/Hypromellose 3cp (43) } \\
\text { Macrogols (hydrophilic polish) (43) }\end{array}$ & $\begin{array}{l}\text { Macrogols (hydrophilic polish) } \\
\text { Polyethylene glycol (hydrophilic polish) (43) } \\
\text { Hypromellose (24) } \\
\text { Polydextrose (43) } \\
\text { Titanium dioxide as white pigment (43) }\end{array}$ \\
\hline Plasticizer & & $\begin{array}{l}\text { Triacetin (43) } \\
\text { Glycerol triacetate (43) }\end{array}$ \\
\hline Polishing Agent & Carnauba wax (25) & \begin{tabular}{l} 
Carnauba wax (25) \\
\hline
\end{tabular} \\
\hline
\end{tabular}




\section{Dynamic Mechanical Thermal Analysis}

$\mathrm{Tg}$ is an important parameter in polymer sciences (13). It is a concept that is demonstrated by both crystalline and amorphous forms and is defined as the temperature at which the material transfers from its glassy state to its rubbery state (34). Paracetamol has a $\mathrm{Tg}$ of around $22.63{ }^{\circ} \mathrm{C}$ (35). In this study, the release was studied for tablets containing a considerably high amount of the drug $(500 \mathrm{mg}$ ), and the assay results were consistent with compendial requirements (Table 1). In this way, the small ratio of the additives is expected to have a minimal influence on $\mathrm{Tg}$, as the results implied. For a poorly compressible, high-dose drug such as paracetamol, it is expected that the additives are used to facilitate compressibility in modest amounts (36). As a result, the effect of polymers and plasticizers would not be expected to significantly minimize $\mathrm{Tg}$ because they were added in small amounts, and it was expected that lower Tg would indicate a rubbery matrix and subsequent enhanced release (i.e., lower $\mathrm{Tg}$ would probably indicate a faster release) (12). There was no strong correlation found between the $\mathrm{Tg}$ and the release profile of the examined materials in this study.

In summary, we performed a comparison between the dissolution profiles of five commercially available paracetamol products. Results indicate that compendial requirements are satisfied in the tested formulations. Nevertheless, the early release stages were not similar for product 2, which showed low release at $15 \mathrm{~min}$. Moreover, the release at the non-compendial $\mathrm{pH} 1.2$ showed significantly lower release for all formulations. In light of those results, the question is whether or not this variation in release would affect the extent of absorption at a certain point, since the drug must be in solution to complete the known biopharmaceutical process of absorption, distribution metabolism, and elimination. In other perspectives, would the design of drug affect its release pattern, and would the early stages of release affect the bioavailability? This acquired knowledge may be employed to define target product quality, develop a product, and design a manufacturing method. In this way, this investigation could be a suitable indicator of the significance of the design, because certain formulations did not exhibit similar release at early stages despite their fulfillment of the compendial requirements.

\section{CONCLUSION}

This study was conducted on commercially available paracetamol tablets. Paracetamol is a weak acid and is expected to have a slow release at low $\mathrm{pH}$. Although the release of all tested products met the compendial requirements, our results showed that $\mathrm{pH}$ significantly affected dissolution rate, which questions the reliability of the USP compendial testing alone. Assay, disintegration, and dissolution testing at $\mathrm{pH} 5.8$ were compatible with the compendial requirements. Tg did not influence the pattern of dissolution rate, probably due to the high drug:polymer excipients ratio, which minimizes the effect of polymer relaxation. This study of commercially available products highlights the importance of postmarket evaluation of finished products. Special attention must be paid to dissolution testing, even for immediaterelease formulations, while keeping in mind the quality and expected efficacy of the finished product in order to increase the return in the market.

\section{ACKNOWLEDGEMENTS}

This project was financially supported by the Deanship of Academic Research and Graduate Studies at Al-Zaytoonah University of Jordan (grant nos. 10/34/2015).

\section{CONFLICTS OF INTEREST}

The authors disclosed no conflicts of interest related to this article.

\section{REFERENCES}

1. Kostewicz, E. S.; Abrahamsson, B.; Brewster, M.; Brouwers, J.; Butler, J.; Carlert, S.; Dickinson, P. A.; Dressman, J.; Holm, R.; Klein, $\mathrm{S}$. In vitro models for the prediction of in vivo performance of oral dosage forms. Eur. J. Pharmaceut. Sci. 2014, 57, 342-366. DOI: 10.1016/j.ejps.2013.08.024.

2. Schneeweiss, S., Developments in post-marketing comparative effectiveness research. Clin. Pharmacol. Ther. 2007, 82, 143156. DOI: 10.1038/sj.clpt.6100249.

3. Sinko, P.; Martin, A. N. Drug release and dissolution. In Martin's Physical and Pharmaceutical Sciences, 6th ed. Sinko, P. J.; Singh, Y., Eds.; Wolters Kluwer, Linpicort Williams \& Wilkins: Baltimore, MD, 2011; pp 310-311.

4. Chandrasekaran, A.; Han, C. Y.; Chung, A. C. Y.; Cheang, L. W.; Ping, L. S. Post market in vitro equivalency evaluation of paracetamol tablets in Kedah, Malaysia. Int. J. Pharm. Sci. Nanotech. 2011, 4, 1403-1407.

5. Dokoumetzidis, A.; Macheras, P. A century of dissolution research: from Noyes and Whitney to the biopharmaceutics classification system. Int. J. Pharm. 2006, 321, 1-11. DOI: 10.1016/j.jpharm.2006.07.011.

6. Markopoulos, C.; Andreas, C. J.; Vertzoni, M.; Dressman, J.; Reppas, C. In-vitro simulation of luminal conditions for evaluation of performance of oral drug products: choosing the appropriate test media. Eur. J. Pharmaceut. Biopharmaceut. 2015, 93, 173182. DOI:10.1016/j.ejpb.2015.03.009.

7. Dressman, J. B.; Berardi, R. R.; Dermentzoglou, L. C.; Russell, T. L.; Schmaltz, S. P.; Barnett, J. L.; Jarvenpaa, K. M. Upper gastrointestinal (GI) $\mathrm{pH}$ in young, healthy men 
and women. Pharmaceut. Res. 1990, 7, 756-761. DOI: 10.1023/A:1015827908309.

8. Waiver of In Vivo Bioavailability and Bioequivalence Studies for Immediate-Release Solid Oral Dosage Forms Based on a Biopharmaceutics Classification System; Guidance for Industry; U.S. Department of Health and Human Services, Food and Drug Administration, Center for Drug Evaluation and Research (CDER), U.S. Government Printing Office: Washington, DC, 2000.

9. Anand, O.; Lawrence, X. Y.; Conner, D. P.; Davit, B. M., Dissolution testing for generic drugs: an FDA perspective. AAPS J. 2011, 13, 328. DOI: 10.1208/s12248-011-9272-y.

10. The United Pharmacopoeia and National Formulary USP 23NF 18; The United States Pharmacopoeial Convention, Inc.: Rockville, MD, 1995; p 1235.

11. Grassi, M.; Grassi, G.; Lapasin, R.; Colombo, I. Understanding Drug Release and Absorption Mechanisms: A Physical and Mathematical Approach. CRC Press, 2006.

12. Omelczuk, M. O.; McGinity, J. W., The influence of polymer glass transition temperature and molecular weight on drug release from tablets containing poly (DL-lactic acid). Pharmaceut. Res. 1992, 9, 26-32.

13. Jones, D. S.; Tian, Y.; Abu-Diak, O.; Andrews, G. P. Pharmaceutical applications of dynamic mechanical thermal analysis. Adv. Drug Deliv. Rev. 2012, 64, 440-448. DOI: 10.1016/j.addr.2011.12.002.

14. Tomuta, I.; Rus, L.; lovanov, R.; Rus, L. L. High-throughput NIRchemometric methods for determination of drug content and pharmaceutical properties of indapamide tablets. J. Pharmaceut. Biomed. Anal. 2013, 84, 285-292. DOI: 10.1016/j. jpba.2012.07.026.

15. Lloyd, G.; Craig, D.; Smith, A. An investigation into the melting behavior of binary mixes and solid dispersions of paracetamol and PEG 4000. J. Pharmaceut. Sci. 1997, 86, 991-996. DOI: 10.1021/js970137w.

16. Kalantzi, L.; Reppas, C.; Dressman, J.; Amidon, G.; Junginger, H.; Midha, K.; Shah, V.; Stavchansky, S.; Barends, D. M. Biowaiver monographs for immediate release solid oral dosage forms: acetaminophen (paracetamol). J. Pharmaceut. Sci. 2006, 95, 4-14. DOI: 10.1002/jps.20477.

17. Cordella, C.; Moussa, I.; Martel, A.-C.; Sbirrazzuoli, N.; LizzaniCuvelier, L. Recent developments in food characterization and adulteration detection: technique-oriented perspectives. J. Agr. Food Chem. 2002, 50, 1751-1764. DOI: 10.1021/jf011096z.

18. Shi, R.; Liu, Q.; Ding, T.; Han, Y.; Zhang, L.; Chen, D.; Tian, W. Ageing of soft thermoplastic starch with high glycerol content. J. Appl. Polym. Sci. 2007, 103, 574-586. DOI: 10.1002/app.25193.

19. Tsume, Y.; Mudie, D. M.; Langguth, P.; Amidon, G. E.; Amidon, G. L. The Biopharmaceutics Classification System: subclasses for in vivo predictive dissolution (IPD) methodology and IVIVC. Eur. J. Pharmaceut. Sci. 2014, 57, 152-163. DOI: 10.1016/j. ejps.2014.01.009.

20. Battu, S. K.; Repka, M. A.; Majumdar, S.; Rao Y, M. Formulation and evaluation of rapidly disintegrating fenoverine tablets: effect of superdisintegrants. Drug Dev. Ind. Pharm. 2007, 33, 1225-1232. DOI: 10.1080/03639040701377888.

21. Krieg, B. J.; Taghavi, S. M.; Amidon, G. L.; Amidon, G. E. In vivo predictive dissolution: comparing the effect of bicarbonate and phosphate buffer on the dissolution of weak acids and weak bases. J. Pharmaceut. Sci. 2015, 104, 2894-2904. DOI: 10.1002/ jps.24460.

22. Fukui, E.; Miyamura, N.; Kobayashi, M., An in vitro investigation of the suitability of press-coated tablets with hydroxypropylmethylcellulose acetate succinate (HPMCAS) and hydrophobic additives in the outer shell for colon targeting. J. Control. Rel. 2001, 70, 97-107. DOI: 10.1016/S01683659(00)00332-1.

23. Karmakar, P.; Kibria, M. G. In-vitro comparative evaluation of quality control parameters between paracetamol and paracetamol/caffeine tablets available in Bangladesh. Int.Curr. Pharmaceut. J. 2012, 1, 103-109.

24. Afifi, S. A.; Al Gohary, O. M. N.; Al-Shalabi, R.; Eltahir, E. K. D.; Darwish, H. W. Comparative evaluation of the pharmaceutical and chemical equivalence of some commercial brands of acetaminophen tablets. Life Sci. J. 2013, 10, 2385-2391.

25. Leuner, C.; Dressman, J., Improving drug solubility for oral delivery using solid dispersions. Eur. J. Pharmaceut. Biopharmaceut. 2000, 50, 47-60. DOI: 10.1016/S0939-6411(00)00076-X.

26. Pinto, J. T.; Brachkova, M. I.; Fernandes, A. I.; Pinto, J. F. Evaluation of the ability of powdered milk to produce minitablets containing paracetamol for the paediatric population. Chem. Eng. Res. Des. 2016, 110, 171-182. DOI: 10.1016/j.cherd.2016.04.014.

27. Ji, Y.; Lemberg, M.; Prudic, A.; Paus, R.; Sadowski, G. Modeling and analysis of dissolution of paracetamol/Eudragit ${ }^{\circledR}$ formulations. Chem. Eng. Res. Des. 2017, 121, 22-31. DOI: 10.1016/j.cherd.2017.03.007.

28. Grattan, T.; Hickman, R.; Darby-Dowman, A.; Hayward, M.; Boyce, M.; Warrington, S. A five way crossover human volunteer study to compare the pharmacokinetics of paracetamol following oral administration of two commercially available paracetamol tablets and three development tablets containing paracetamol in combination with sodium bicarbonate or calcium carbonate. Eur. J. Pharmaceut. Biopharmaceut. 2000, 49, 225-229. DOI: 10.1016/S0939-6411(00)00081-3.

29. Rostami-Hodjegan, A.; Shiran, M.; Ayesh, R.; Grattan, T.; Burnett, I.; Darby-Dowman, A.; Tucker, G. A new rapidly absorbed paracetamol tablet containing sodium bicarbonate. I. A four-way crossover study to compare the concentration-time profile of paracetamol from the new paracetamol/sodium bicarbonate tablet and a conventional paracetamol tablet in fed and fasted volunteers. Drug Dev. Ind. Pharm. 2002, 28, 523-531. DOI: 10.1081/DDC-120003448.

30. Shihora, H.; Panda, S. Superdisintegrants, utility in dosage forms: a quick review. J. Pharm. Sci. Biosci. Res. 2011, 1, 148-53.

31. Gohel, M. C.; Parikh, R. K.; Brahmbhatt, B. K.; Shah, A. R. Preparation and assessment of novel coprocessed 
superdisintegrant consisting of crospovidone and sodium starch glycolate: a technical note. AAPS PharmSciTech. 2007, 8, E63E69. DOI: 10.1208/pt0801009.

32. Tønnesen, H. H.; Karlsen, J. Alginate in drug delivery systems. Drug Dev. Ind. Pharm. 2002, 28, 621-630. DOI: 10.1081/DDC120003853.

33. Espeau, P.; Céolin, R.; Tamarit, J. L.; Perrin, M. A.; Gauchi, J. P.; Leveiller, F. Polymorphism of paracetamol: relative stabilities of the monoclinic and orthorhombic phases inferred from topological pressure-temperature and temperature-volume phase diagrams. J. Pharmaceut. Sci. 2005, 94, 524-539. DOI: 10.1002/jps.20261.

34. Jadhav, N.; Gaikwad, V.; Nair, K.; Kadam, H. Glass transition temperature: basics and application in pharmaceutical sector. Asian J. Pharmaceut. 2009, 3, 82.

35. Di Martino, P.; Palmieri, G. F.; Martelli, S. Molecular mobility of the paracetamol amorphous form. Chem. Pharmaceut. Bull. 2000, 48, 1105-1108.

36. Aulton, M. E. Dissolution and solubility. In Aulton's Pharmaceutics E-Book: The Design and Manufacture of Medicines; Aulton, M. E.; Taylor, K., Eds. Churchill Livingstone, 2013; p 20.

37. Kilor, V. A.; Sapkal, N. P.; Awari, J. G.; Shewale, B. D. Development and characterization of enteric-coated immediate-release pellets of aceclofenac by extrusion/spheronization technique using k-carrageenan as a pelletizing agent. AAPS PharmSciTech. 2010, 11, 336-343. DOI: 10.1208/s12249-010-9389-9.

38. Patel, H.; Shah, V.; Upadhyay, U. New pharmaceutical excipients in solid dosage forms-A review. Int. J. Pharm. Life Sci. 2011, 2, 1006-1019.

39. Jannin, V.; Cuppok, Y. Hot-melt coating with lipid excipients. Int. J. Pharmaceut. 2013, 457, 480-487. DOI: 10.1016/j. ijpharm.2012.10.026.

40. Desai, D.; Wong, B.; Huang, Y.; Tang, D.; Hemenway, J.; Paruchuri, S.; Guo, Hsieh, D.; Timmins, P. Influence of dissolution media
$\mathrm{pH}$ and USP1 basket speed on erosion and disintegration characteristics of immediate release metformin hydrochloride tablets. Pharmaceut. Dev. Technol. 2015, 20, 540-545. DOI: 10.3109/10837450.2014.892132.

41. Jivraj, M.; Martini, L. G.; Thomson, C. M. An overview of the different excipients useful for the direct compression of tablets. Pharmaceut. Sci. Technol. Today 2000, 3, 58-63. DOI: 10.1016/ S1461-5347(99)00237-0.

42. Bamiro, O. A.; Sinha, V. R.; Kumar, R.; Odeku, O. Characterization and evaluation of Terminalia randii gum as a binder in carvedilol tablet formulation. Acta Pharm. Sci. 2010, 52, 254-262.

43. Rowe, R. C.; Sheskey, P. J.; Quinn, M. Handbook of pharmaceutical excipients-7th edition. Pharm. Dev. Technol. 2013, 18, 544. DOI: 10.3109/10837450.2012.751408.

44. Crovetto, S. I.; Moreno, E.; Dib, A. L.; Espigares, M.; Espigares, E. Bacterial toxicity testing and antibacterial activity of parabens. Toxicol. Environ.Chem. 2017, 99, 1-11. DOI: 10.1080/02772248.2017.1300905

45. 45. Dan, J.; Ma, Y.; Yue, P.; Xie, Y.; Zheng, Q.; Hu, P.; Zhu, W.; Yang, M. Microcrystalline cellulose-carboxymethyl cellulose sodium as an effective dispersant for drug nanocrystals: A case study. Carbohydr. Polym. 2016, 136, 499-506. DOI: 10.1016/j. carbpol.2015.09.048.

46. Bushra, R.; Shoaib, M. H.; Aslam, N.; Mehmood, Z. A.; Hashmat, D. Enteric coating of ibuprofen tablets ( $200 \mathrm{mg}$ ) using an aqueous dispersion system. Brazilian J Pharmaceut. Sci. 2010, 46, 99-107. DOI: 10.1590/S1984-82502010000100011.

47. Aleksovski, A.; Dreu, R.; Gašperlin, M.; Planinšek, O. Minitablets: a contemporary system for oral drug delivery in targeted patient groups. Exp. Op. Drug Del. 2015, 12, 65-84. DOI: 10.1517/17425247.2014.951633. 